\title{
ANAESTHETIC COMPLICATIONS IN SURGICAL OUT-PATIENTS
}

\author{
G. Fred Brindle and Magdi G. Soliman
}

THE NUMBER OF OUT-PATIENTS receiving surgical treatment necessitating general anaesthesia has increased dramatically in the past five years. Various psychological, economic, medical and social factors are behind this increase.

Since all our patients are entitled to hospitalization for surgery, there is no economic motivation to stimulate such patients to undergo the discomfort of immediate post-operative travel and convalescence at home. In the group of patients presented here, the psychological advantages were certainly less important than in the case of children. The safety of out-patient surgery depends mainly on patient selection, the type of operation and the anaesthetic technique. We therefore thought it might be of some interest to evaluate anaesthetic sequelae and how these patients fared in the first five days following operation.

\section{MEthod}

Five hundred female patients (ASA class I) were the subjects of this study. All underwent tubal electrocoagulation through a laparoscope as out-patients.

After an interval varying from one week to four months post-operatively, each patient received a questionnaire designed to determine the incidence and severity of post-anaesthetic complications (headache, nausea, vomiting, muscular pains, sore throat, cough, expectorations, dizziness, orthostatic dizziness and inability to concentrate) and the time needed for full recovery as indicated by the time before returning to work and that required for complete return to pre-operative status.

The severity of any complication was defined by its duration and graded as:

$$
\begin{aligned}
& \text { Mild - duration less than } 48 \text { hours } \\
& \text { Moderate-duration two-five days } \\
& \text { Severe - persisted longer than five days }
\end{aligned}
$$

The criteria for recovery are of course subjective evaluations made by the patients. Patients were also asked to comment generally about the operation and to state whether or not they would be prepared to repeat the experience as an outpatient.

\section{Anaesthetic Management}

Several anaesthetic agents were used for induction and maintenance, although an attempt was made to adhere to certain principles of management.

No premedication was given unless the patient was very nervous. Consequently

Department of Anaesthesia, Centre Hospitalier Universitaire, Sherbrooke, Quebec. 
TABLE I

Muscular Pain

\begin{tabular}{|c|c|c|c|c|c|c|c|c|}
\hline \multirow{3}{*}{$\begin{array}{c}\text { No. of } \\
\text { answers }\end{array}$} & & & \multicolumn{6}{|c|}{ Duration } \\
\hline & \multicolumn{2}{|c|}{ Incidence } & \multicolumn{2}{|c|}{$48 \mathrm{hrs}$} & \multicolumn{2}{|c|}{$2-5$ days } & \multicolumn{2}{|c|}{$>5$ days } \\
\hline & No. & $\%$ & No. & $\%$ & No. & $\%$ & No. & $\%$ \\
\hline 418 & 180 & 43 & 86 & 48 & 93 & 51.5 & 1 & 0.5 \\
\hline
\end{tabular}

TABLE II

Sore Throat

\begin{tabular}{|c|c|c|c|c|c|c|}
\hline \multirow{3}{*}{$\begin{array}{c}\text { No. of } \\
\text { answers }\end{array}$} & & & \multicolumn{4}{|c|}{ Duration } \\
\hline & \multicolumn{2}{|c|}{ Incidence } & \multicolumn{2}{|c|}{$48 \mathrm{hrs}$} & \multicolumn{2}{|c|}{$2-5$ days } \\
\hline & No. & $\%$ & No. & $\%$ & No. & $\%$ \\
\hline 418 & 118 & 28.2 & 80 & 7.8 & 38 & 32.2 \\
\hline
\end{tabular}

TABLE III

HEAdaChE

\begin{tabular}{|c|c|c|c|c|c|c|}
\hline \multirow{3}{*}{$\begin{array}{c}\text { No. of } \\
\text { answers }\end{array}$} & & & \multicolumn{4}{|c|}{ Duration } \\
\hline & \multicolumn{2}{|c|}{ Incidence } & \multicolumn{2}{|c|}{$48 \mathrm{hrs}$} & \multicolumn{2}{|c|}{$2-5$ days } \\
\hline & No. & $\%$ & No. & $\%$ & No. & $\%$ \\
\hline 418 & 71 & 17 & 51 & 72 & 20 & 28 \\
\hline
\end{tabular}

TABLE IV

NAUSEA

\begin{tabular}{|c|c|c|c|c|c|c|}
\hline \multirow{3}{*}{$\begin{array}{l}\text { No. of } \\
\text { answers }\end{array}$} & & & \multicolumn{4}{|c|}{ Duration } \\
\hline & \multicolumn{2}{|c|}{ Incidence } & \multicolumn{2}{|c|}{$48 \mathrm{hrs}$} & \multicolumn{2}{|c|}{$2-5$ days } \\
\hline & No. & $\%$ & No. & $\%$ & No. & $\%$ \\
\hline 418 & 65 & 15.5 & 52 & 80 & 13 & 20 \\
\hline
\end{tabular}

TABLE $V$

VOMITING

\begin{tabular}{|c|c|c|c|c|c|c|}
\hline \multirow{3}{*}{$\begin{array}{c}\text { No. of } \\
\text { answers }\end{array}$} & & & \multicolumn{4}{|c|}{ Duration } \\
\hline & \multicolumn{2}{|c|}{ Incidence } & \multicolumn{2}{|c|}{$48 \mathrm{hrs}$} & \multicolumn{2}{|c|}{ 2-5 days } \\
\hline & No. & $\%$ & No. & $\%$ & No. & $\%$ \\
\hline 418 & 34 & 8 & 32 & 94 & 2 & 6 \\
\hline
\end{tabular}


only 18 per cent of patients received premedication in the form of 5-10 mg diazepam intramuscularly about one hour before induction. Atropine $0.4 \mathrm{mg}$ was given intravenously to all patients just before induction.

In about half the patients anaesthesia was induced with a sleeping dose of thiopentone, while in the remainder methohexitone was used.

The tracheae of all patients were intubated after a paralyzing dose of succinylcholine $(1 \mathrm{mg} / \mathrm{kg}$ ); in about 60 per cent of the patients 3-6 mg of D-tubocurare was given prior to the succinylcholine to decrease muscle faciculations.

Anaesthesia was maintained in all patients with nitrous oxide and oxygen and 0.1 per cent succinylcholine drip; halothane was added in 40 per cent of cases. Innovar in 20 per cent, supplemental methohexitone in 20 per cent and combinations of more than one agent in the rest of the patients.

There were no immediate anaesthetic complications; most patients were discharged within three hours and none required post-anaesthetic admission as inpatients.

\section{RESULTS}

Four hundred and eighteen patients ( 83.6 per cent) returned the questionnaire. The answers showed that post anaesthetic complications were frequent. Their nature and severity are shown in tables I-IX.

Muscle pains were the most common complication - the incidence was 45 per cent and in more than 51.5 per cent of these was of moderate severity. In only one patient did pain persist for more than five days (Table I).

The incidence of post-operative sore throat was fairly high at 28.2 per cent but in the majority of cases it was mild (Table II).

Headache, nausea, vomiting, cough and sputum were common with incidence of 8 per cent to 17 per cent. In the majority of the patients these complications were of mild nature (Tables III-VII).

The incidence of recumbent and orthostatic dizziness was fairly high; however, in the majority it was mild (Tables VIII and IX).

Thirty per cent of patients experienced inability to concentrate. It lasted more than two days in about half of them (Table X).

The time to complete recovery is shown in tables XI and XII: 32.9 per cent of the patients were able to do their habitual work within 48 hours. However, 57.9 per cent took two to five days to do so, while the rest took more than five days before they were able to carry out their usual work (Table XI).

The duration before return to preoperative mental status is shown in Table XII. Only 12 per cent of patients had fully recovered within 48 hours while 67.2 per cent took two to five days and 20.8 per cent of patients required more than five days.

Table XIII shows the recall for the day of operation. The large majority remembered it very well. Only one patient had poor recall for that day.

The opinion of the patients regarding their treatment as indicated by their willingness to undergo the same procedure again is shown in table XIV. Eighty-one per cent would accept the procedure again, 16.7 per cent would refuse it, and 10 patients did not give any definite answer. 
TABLE VI

Covgh

\begin{tabular}{|c|c|c|c|c|c|c|}
\hline \multirow{3}{*}{$\begin{array}{c}\text { No. of } \\
\text { answers }\end{array}$} & & & \multicolumn{4}{|c|}{ Duration } \\
\hline & \multicolumn{2}{|c|}{ Incidence } & \multicolumn{2}{|c|}{$48 \mathrm{hrs}$} & \multicolumn{2}{|c|}{$2-5$ days } \\
\hline & No. & $\%$ & No. & $\%$ & No. & $\%$ \\
\hline 418 & 66 & 15.8 & 42 & 63.6 & 24 & 36.4 \\
\hline
\end{tabular}

TABLE VII

EXPECTORATIONS

\begin{tabular}{|c|c|c|c|c|c|c|}
\hline \multirow{3}{*}{$\begin{array}{c}\text { No. of } \\
\text { answers }\end{array}$} & & & \multicolumn{4}{|c|}{ Duration } \\
\hline & \multicolumn{2}{|c|}{ Incidence } & \multicolumn{2}{|c|}{$48 \mathrm{hrs}$} & \multicolumn{2}{|c|}{$2-5$ days } \\
\hline & No. & $\%$ & No. & $\%$ & No. & $\%$ \\
\hline 418 & 37 & 8.8 & 32 & 62 & 14 & 38 \\
\hline
\end{tabular}

TABLE VIII

Dizziness

\begin{tabular}{|c|c|c|c|c|c|c|c|c|}
\hline \multirow{3}{*}{$\begin{array}{c}\text { No. of } \\
\text { answers }\end{array}$} & & & \multicolumn{6}{|c|}{ Duration } \\
\hline & \multicolumn{2}{|c|}{ Incidence } & \multicolumn{2}{|c|}{$48 \mathrm{hrs}$} & \multicolumn{2}{|c|}{$2-5$ days } & \multicolumn{2}{|c|}{$>5$ days } \\
\hline & No. & $\%$ & No. & $\%$ & No. & $\%$ & No. & $\%$ \\
\hline 418 & 171 & 41 & 116 & 67.8 & 54 & 31.6 & 1 & 0.6 \\
\hline
\end{tabular}

TABLE IX

Orthostatic Dizziness

\begin{tabular}{|c|c|c|c|c|c|c|c|c|}
\hline \multirow{3}{*}{$\begin{array}{c}\text { No. of } \\
\text { answers }\end{array}$} & & & \multicolumn{6}{|c|}{ Duration } \\
\hline & \multicolumn{2}{|c|}{ Incidence } & \multicolumn{2}{|c|}{$48 \mathrm{hrs}$} & \multicolumn{2}{|c|}{$2-5$ days } & \multicolumn{2}{|c|}{$>5$ days } \\
\hline & No. & $\%$ & No. & $\%$ & No. & $\%$ & No. & $\%$ \\
\hline 418 & 139 & 33.2 & 111 & 79.9 & 27 & 19.4 & 1 & 0.7 \\
\hline
\end{tabular}

TABLE $X$

INABILITy to Concentrate

\begin{tabular}{|c|c|c|c|c|c|c|}
\hline \multirow{3}{*}{$\begin{array}{c}\text { No. of } \\
\text { answers }\end{array}$} & & & \multicolumn{4}{|c|}{ Duration } \\
\hline & \multicolumn{2}{|c|}{ Incidence } & \multicolumn{2}{|c|}{$48 \mathrm{hrs}$} & \multicolumn{2}{|c|}{$2-5$ days } \\
\hline & No. & $\%$ & No. & $\%$ & No. & $\%$ \\
\hline 418 & 126 & 30.1 & 64 & 50.8 & 62 & 49.2 \\
\hline
\end{tabular}


TABLE XI

ReTURN to Habitual Work

\begin{tabular}{|c|c|c|c|c|c|c|}
\hline \multirow{2}{*}{$\begin{array}{l}\text { No. of } \\
\text { answers }\end{array}$} & \multicolumn{2}{|c|}{ Within $48 \mathrm{hrs}$} & \multicolumn{2}{|c|}{ Within $2-5$ days } & \multicolumn{2}{|c|}{ Within $>5$ days } \\
\hline & No. & $\%$ & No. & $\%$ & No. & $\%$ \\
\hline 411 & 135 & 32.9 & 238 & 57.9 & 38 & 9.2 \\
\hline
\end{tabular}

TABLE XII

Feeling of Complete Recovery

\begin{tabular}{|c|c|c|c|c|c|c|}
\hline \multirow{2}{*}{$\begin{array}{c}\text { No. of } \\
\text { answers }\end{array}$} & \multicolumn{2}{|c|}{ Within 48 hrs } & \multicolumn{2}{|c|}{ Within $2-5$ days } & \multicolumn{2}{|c|}{ Within $>5$ days } \\
\hline & No. & $\%$ & No. & $\%$ & No. & $\%$ \\
\hline 408 & 49 & 12 & 274 & 67.2 & 85 & 20.8 \\
\hline
\end{tabular}

TABLE XIII

Memory Operation Day

\begin{tabular}{|c|c|c|c|c|c|c|}
\hline \multirow{2}{*}{$\begin{array}{c}\text { No. of } \\
\text { answers }\end{array}$} & \multicolumn{2}{|c|}{ Very well } & \multicolumn{2}{|c|}{ Moderate } & \multicolumn{2}{|c|}{ Poor } \\
\hline & No. & $\%$ & No. & $\%$ & No. & $\%$ \\
\hline 414 & 366 & 88.4 & 44 & 10.6 & 4 & 1 \\
\hline
\end{tabular}

TABLE XIV

Accept the Procedure Again

\begin{tabular}{ccccccccc}
\hline & \multicolumn{2}{c}{ Yes } & & \multicolumn{2}{c}{ No } & & \multicolumn{2}{c}{$\begin{array}{c}\text { No definite } \\
\text { response }\end{array}$} \\
\cline { 2 - 3 } \cline { 8 - 9 } $\begin{array}{c}\text { No. of } \\
\text { answers }\end{array}$ & No. & $\%$ & & No. & $\%$ & & No. & $\%$ \\
\hline 418 & 338 & 80.9 & & 70 & 16.7 & & 10 & 2.4 \\
\hline
\end{tabular}

\section{Discussion}

This study shows that out-patient anaesthesia is not free of complications. However, most of these complications with the exception of muscle pains had a low incidence and a relatively benign course.

The incidence of nausea, vomiting, headache, sore throat, and dizziness reported in this study were not much different from those reported by Thompson, et al. in patients anaesthetized with barbiturates. ${ }^{1}$

Full recovery from general anaesthesia is a very important consideration. It has been shown ${ }^{2}$ that it may take up to one week before full mental recovery following general anaesthesia. Our results are in agreement with these observations, which are of concern to both patients and anaesthetists. The patient should be instructed to avoid making major decisions, to avoid drugs which potentiate the residual effect of the anaesthetic agents, as for instance alcohol and not to undertake compli- 
cated tasks such as driving an automobile or operating other hazardous machinery, since he may lack the necessary fine judgment and co-ordination for some time.

While the complications listed are not serious they do indicate, however, that the advantages of out-patient surgery are paid for by having a patient returned to his home in less than ideal condition. The geographical location of our hospital in a rural setting means that our patients may have to travel as much as 60 miles between hospital and home. Despite this uncomfortable journey, over 80 per cent of the patients believed the price exacted was acceptable.

Further studies with newer agents such as Althesin might show that return of normal cerebral function can perhaps be accelerated, thus reducing the danger of accidents after patients are discharged. To date none of our patients has had an accident following discharge from hospital. It is perhaps more good luck than good management, for there are surely some irresponsible patients who, notwithstanding instructions, do in fact consume alcoholic beverages or drive their automobiles after the anaesthetic.

\section{SUMMARY}

This study reports retrospectively the post-anaesthetic complications in surgical out-patients. We have studied the incidence and severity of these complications during the first five post-operative days in 500 female patients who underwent tubal ligation by laparoscopy.

The report shows that post-anaesthetic complications in surgical out-patients are frequent but of mild severity. Although they produced some discomfort for the patients most of them were of the opinion that the advantages of having the operation as out-patients made up for the discomfort.

\section{RÉSUMÉ}

Cette étude rapporte de façon rétrospective les complications post-anesthésiques lors de chirurgie chez des patients admis sur base externe. Nous avons étudié l'incidence et la sévérité de ces complications durant les cinq premiers jours post-opératoires chez 500 patientes, ayant subi une ligature tubaire par laparoscopie.

L'enquête a montré que les complications post-anesthésiques chez ces patientes sont fréquentes mais d'importance mineure. La plupart des patientes affirmaient que les avantages de la chirurgie effectuée sur base externe compensaient amplement l'inconfort ressenti à domicile.

\section{REFERENCES}

1. Thompson, G.E., Remington, J.M., Millman, B.S., \& Bridenbaugh, L.D. Experiences with out-patient anaesthesia. Anesthesia \& Analgesia ... Current Researches 52 (6): 881 (1973)

2. Fahy, A. \& Marshald, M. Post anaesthetic morbidity in out-patients. British Journal of Anaesthesia 41: 433 (1969).

3. STEwARD, D.J. Experiences with an out-patient anaesthesia service for children. Anesthesia \& Analgesia ... Current Researches 52 (6): 877 (1973). 
4. Conen, D.D. \& Dillon, J.B. Anesthesia for out-patient surgery. J.A.M.A. 196 (13): 98 (1966).

5. Treloar, E.J. An outpatient anaesthetic service: standards and organization. Can. Anaes. Soc. J. 14 (6): 596 (1967).

6. Doenicke, A., Kugler, J., \& Laub, M. Evaluation of recovery and "street fitness" by E.E.C. and psychodiagnostic tests after anaesthesia. Can. Anaes. Soc. J. 14 (6): 567 (1966).

7. Brindle, G.F., Lamarche, Y., \& Soliman, M.G. L'anesthésie du malade ambulatoire Expérience de 2,500 cas. Annales de l'Anesthésiologie Française (in press). 